\title{
Business incubators and green technology: The Gauteng Climate Innovation Centre, South Africa
}

\begin{abstract}
Business incubators are a vehicle to assist the survival prospects of start-up enterprises, many of which fail in their early years of operation. One special form of business incubator is the Climate Innovation Centre (CIC) which is part of international debates around green economies and appropriate technologies for climatecompatible development. CICs are an intervention to build innovation sites to ameliorate climate change and a highly distinctive form of business incubator in which the explicit focus is upon supporting small business startups allied to the application of green technologies. Using a qualitative approach the article analyses the establishment and operations of the Gauteng Climate Innovation Centre in South Africa. The CICSA in its first five years of operations has been 'learning through experience' and introduced a number of changes since its launch in 2012, including an extension of the business incubation programme and an adjusted focus to South Africa's climate change related 'green' issues around energy, water and waste. Although 5 years is too short for a conclusive evaluation of CIC operations the evidence from this research with South African clean-tech enterprises is largely positive and suggests that the assistance provided by the CIC has contributed towards enterprise development.
\end{abstract}

Keywords: business incubators, small enterprise development, green technology, climate innovation centre, South Africa

\section{Introduction}

The positive health of the small business economy is viewed as crucial for current and future economic development prospects in sub-Saharan Africa (Rogerson, 2018a). This said, among newly established enterprises in their early and most vulnerable stages of existence there are recorded high rates of mortality. Arguably, a host of challenges impact the growth and survival of small enterprises in Africa, most importantly lack of market opportunities, limited access to finance, severe infrastructural deficits (especially power shortages), and a weakly evolved business environment with complex regulatory processes, corruption and often minimal public sector assistance (InfoDev, 2016). From the international experience the expanded support for business incubation and the establishment of physical (as well as virtual) business incubators is advocated as one means for addressing the disappointing survival rates of newly established small enterprises and including those in Africa (Ndabeni, 2008; InfoDev, 2010a; Masutha \& Rogerson, 2014a, 2014b; Albort-Morant \& RibieroSoriano, 2016; Rogerson, 2016a).

With historical roots in North America as well as Western Europe the activity of business incubation has spread into a global phenomenon and increasingly is embedded as part of broader policy initiatives designed to foster innovation, entrepreneurship and business development both in transitional economies as well as developing countries of the global South (Akcomak, 2009; InfoDev, 2010b, 2010c; Al-Mubaraki et al., 2013; Al-Mubaraki \& Busler, 2014; InfoDev, 2014; Theodorakopoulos et al., 2014; Rogerson, 2016a; Li \& North, 2018). Business incubation is endorsed as a positive developmental approach by a number of 
international development agencies. The Information for Development (InfoDev) programme of the World Bank uses the following definition of business incubation. This is "a process aimed at supporting the development and scaling of growth-oriented early-stage enterprises. The process provides entrepreneurs with an enabling environment at the start-up stage of enterprise development. This environment should help reduce the cost of launching the enterprise, increase the confidence and capacity of the entrepreneur and link the entrepreneur to resources required to start and scale a competitive enterprise" (InfoDev, 2014: 8).

Within the international literature several variants of business incubator are identified and definitions contested of what actually constitutes an incubator (Grimaldi \& Grandi, 2005; InfoDev, 2010a; Bruneel et al., 2012; Rogerson, 2016a). Broad agreement exists that business incubators supply a number of targeted business and technical support services which seek to nurture emerging and small start-up business enterprises into financially and operationally independent ventures (Theodorakopoulos et al., 2014; Albort-Morant \& Ribiero-Soriano, 2016). Grimaldi and Grandi (2005: 112) assert that the development of business incubators aims to reduce "the costs of doing business by offering a set of services ranging from the provision of space, infrastructure and facilities, to more elaborate services, as well as offering access to technical and managerial expertise, assistance in business plan development". Although several international examples of business incubation programmes target what would be described as 'survivalist enterprises' most incubation activity concentrates upon strengthening the business survival prospects of groups of dynamic, growth-oriented earlystage enterprises (Tengeh \& Choto, 2015; Rogerson, 2018a). The latter usually are innovative small enterprises which are seen as critical potential catalysts for future job creation and accompanying economic and social development (Rogerson, 2018b).

With an increasing global adoption of business incubation as a support mechanism for small enterprise development there has occurred a rise in international scholarship and debates about the operations and impacts of business incubators and their different forms (AlbortMorant \& Ribiero-Soriano, 2016; Rogerson, 2016a). Relative to other regions of the world, however, business incubation is "in its infancy on the African continent" (InfoDev, 2016: 3). In one international research overview Mian et al. (2016) note the underdeveloped character of African scholarship surrounding business incubation. There have been certain advances in research to accompany the most established initiatives in Africa which occur in South Africa for applying business incubation as part of the toolkit for small enterprise support (Masutha \& Rogerson, 2014a, 2014b, 2015; Lose et al., 2016; Rogerson, 2018a). Another recent research focus is the impact of business incubators on women entrepreneurs in the continent (Kapinga et al., 2018).

It is against the above background of an emerging African scholarship that the objective in this paper is to contribute to extant literature and debates about business incubation in Africa. The specific focus is to investigate the establishment and progress of initiatives which build upon the potential of green technology for small enterprise development. Our study investigates the establishment of Climate Innovation Centres as business incubators and the emerging experience of the Gauteng Climate Innovation Centre in South Africa. Two further sections of material are presented. The following section reviews briefly the application of green technology and the establishment and remit of an international network of Climate Innovation Centres. Attention turns then to analyse in detail the establishment and operations of South Africa's Climate Innovation Centre. 


\section{Green Technology and Climate Innovation Centres}

At the broadest level of interpretation Climate Innovation Centres (CICs) are part of wider international discussions which are taking place around green economies and the adoption of appropriate technologies for climate-compatible development (Newell \& Bulkeley, 2017; Nunan, 2017). Global interest in the green economy has heightened greatly since the financial crisis of 2008 along with a proliferation of competing discourses about its meaning (BorelSaladin \& Turok, 2013a; Death, 2014). For Georgeson et al. (2017: 1) the green economy represents an attractive framework to deliver more resource efficient, lower carbon and less environmentally damaging as well as more socially inclusive societies. In African debates a green economy is based on principles of sustainable development as it constitutes an economic system in which economic, environmental and social challenges are addressed holistically (Kaggwa et al., 2013). Nhamo (2013) defines a green economy as the enhancement of human-well-being and social equality while taking the environment's importance into account. Notwithstanding critiques that the green economy simply represents 'green-washing' it is argued that it "has the potential to effect substantive and transformative change towards the goal of sustainable development” (Borel-Saladin \& Turok, 2013a: 209).

The foundation for the making of a green economy is green technology or climate technology which represent environmentally friendly innovations usually involving energy efficiency, recycling, renewable energy, and safety or health considerations (Hasper, 2009). Arguably, green technological innovation is essential for sub-Saharan Africa in order to adapt to current climate change conditions but even more so to mitigate future climate change impacts. Environmentally friendly innovations assist in reducing negative human impacts on the environment and are vital for countries to adapt to and mitigate the impacts of current climate change (Sagar \& Bloomberg New Energy Finance, 2010). This said, the transition to a green economy has proven challenging across the global South and, given the significance of climate change, international development organizations recommend the application of development assistance to ease the green economy transition, including the roll out of green technologies associated with CICs. Sagar (2010) affirms that by advancing innovation processes for key climate technologies a critical contribution of these centres is to move forward the process of technology transition in the global South and thereby enable countries to meet their climate challenges both more efficiently and effectively.

As described elsewhere these centres emerged as a particular form of business incubator which is targeted to accelerate the development, deployment and transfer of locally relevant climate technologies (Sagar et al., 2009; Rogerson, 2018a). Within the Climate Technology Programme which links to InfoDev and the World Bank, climate challenges are recast into business opportunities to galvanize the establishment and expansion of innovative dynamic small enterprises (InfoDev, 2010c; Rogerson, 2018b). With appropriate support small entrepreneurs can assist emissions reduction, build climate resilience and enhance the prospects for climate compatible development. At the same time they can enable developing countries to capture greater value in the innovation value chain, establish new competitive sectors, competitive enterprises and encourage new bases for employment opportunities (InfoDev, 2016; Rogerson, 2018a). It is notable that the United Nations system task team on the post-2015 UN Development Agenda recommends that in considering the science, technology and innovation framework for post-2015 that "the global partnership for development should consider developing such centres" (ITU et al., 2015: 10). 
CICs thus can be viewed as green economic initiatives and act as a stepping stone towards climate compatible development. In search of local solutions, the CICs are an intervention to build innovation sites to ameliorate climate change (InfoDev, 2015). They represent a highly distinctive form of business incubator in which the explicit focus is upon nurturing small business start-ups allied to green technologies linked to climate change issues (Rogerson, 2018b). Further CICs represent multilateral, international, national and local interventions that are formed through the cooperation between the relevant departments of the applicable countries in association with international development agencies, most especially with Britain's Department for International Development and the World Bank through InfoDev (Sagar et al., 2009; InfoDev, 2013a, 2013b). For Sagar (2010) initially they were envisaged as an umbrella organization that would have under it a collection of projects that propel the innovation process for core climate change technologies for the particular country or region where the centre is located.

Essentially three fundamental goals drive the global planning and operations of CICs. These are to achieve sustainable development by facilitating the transition to a green economy, support the innovation of green technologies, and make a positive input to climate mitigation and adaptation through contributing to implementation of climate change programmes (Sagar et al., 2009; InfoDev, 2016). In the transition towards climate compatible development the importance is acknowledged of both mitigation and adaptation measures to impact climate change and in particular to reduce global greenhouse gas emissions by speeding up the shift towards environmentally friendly technologies (Sagar et al., 2009). It is acknowledged, however, that such a transition requires extensive research, development, market validation, commercialization and distribution which, in turn, demands new partnership initiatives through the activities of CICs. Necessary partnerships are formed between private and public sectors, between the global North and the global South. and between developing countries themselves within the global South.

The existing international network of CICs extends to seven developing countries (InfoDev, 2016). The pioneer CIC was established at Nairobi in Kenya (InfoDev, 2010c, 2013b). Similar centres followed in Morocco, Vietnam, Jamaica, Ghana, Ethiopia and South Africa. It is estimated that each operational CIC requires financial support of between US\$ 40-100 million per annum (Sagar et al., 2009). Every CIC is planned and developed uniquely according to the host country's requirements, opportunities and barriers (Sagar, 2010). Although each functions independently they rely on one another for assistance as required (Sagar et al., 2009). The existing CICs form a global network which assembles on an annual basis as a "learning environment" for the sharing of experiences, knowledge and information. The concept of a 'global network' of CICs arose from the position that technological and information transfer as well as motivation and support would be made more operational and successful if shared between various CICs (Sagar, 2010). Essentially the global CIC network is evolving with the objective of establishing knowledge platforms, forums, and technology exchange through deepened partnerships to assist clean-tech entrepreneurs (Sagar et al., 2009).

At one level these centres function as dedicated business incubators that operate at a countryscale and assist clean-tech entrepreneurs to establish and grow their businesses, to enhance employment prospects and to create cleaner energy, water, food and air with minimal resource utilisation. In terms of their operations Sagar \& Bloomberg New Energy Finance (2010) stylize CICs as one-stop-shops. The centres can furnish an array of support services that encompass facilitating access to finance, business advice, policy support, education and 
training as well as technical aid (InfoDev, 2013a, 2013b). Together the services and functions provided by the CIC are to avert the so-termed 'valley of death' in which many start-up enterprises fall prey, namely the phase between early growth and market entry when the mortality rates of small enterprises are especially high. Different categories of targeted services that afford support for clean-tech entrepreneurs are recognised across the existing network of operations of CICs. Several services, however, are not directly provided by CICs themselves rather they are sub-contracted to appropriate organizations as service providers for delivery to entrepreneurs (InfoDev, 2013a, 2013b).

Many centres engage in financial assistance for enterprises including venture capital style investments in equity or debt and or via investment facilitation through an international network of investors. Business advice and training is another critical service that usually is given with mentorship support important to enhance business success. Advice is extended to business planning, financial planning, and market information (InfoDev, 2012, 2013a). In terms of business planning this includes guidance towards business plan development, presentation skills, marketing schemes as well as human resource management. Support regarding financial planning is based on investment due-diligence and to ensure that enterprises are suitable for investment. Entrepreneurs are offered skills training applicable to budgeting, accounting, financial predictions and modelling. In addition, CICs offer technical training in the specialist skills around climate technologies. As a complementary activity they offer the latest objective information on the state of climate technologies and of new innovations thereof. Access is made available to technical experts to aid entrepreneurs and heighten their awareness of international knowledge exchange platforms which allow for mutual collaboration and new partnerships especially with the World Bank and its Climate Technology Centre \& Network (InfoDev, 2013a, 2016).

InfoDev (2012) contends that CICs can be channels to facilitate access to international markets as CICs monitor markets and market barriers in order to provide enterprises with comprehensive market information about particular green economy sectors. Policy advocacy is a further contribution of CICs in collaboration with country governments. Information and policy gaps are identified and improvements encouraged through CIC-supported small enterprise feedback as well as continual identification of international best practice (InfoDev, 2012). Finally, as is conventional for physical business incubators, CICs offer shared office and operational space for small enterprise start-ups.

\section{The Gauteng Climate Innovation Centre}

This section turns to the case study on the origins, operations and challenges of the South African CIC. The analysis draws from documentary sources as well as 24 qualitative in-depth semi-structured interviews conducted during 2017 (Gonsalves, 2018). These include with four stakeholders involved in the management and operation of the Gauteng Climate Innovation Centre and 20 interviews with enterprises attached to the business incubator. The sample of 20 interviewed entrepreneurs constitutes almost one-third of the clean-tech enterprises in the CIC's operational portfolio at the time (2017) of the field research.

The establishment of a CIC in South Africa was highly appropriate given that the country faces major developmental challenges as a consequence of the advance of climate change (Ziervogel et al., 2014; Rogerson, 2016b). Southern Africa is one of the most vulnerable regions in the world for climate change impacts with observed and projected temperature 
changes higher than those for other world regions. Scholes et al. (2015) argue South Africa contributes $1.5 \%$ of global greenhouse gas emissions and the country lists under the top 20 worst global greenhouse gas emitters largely because of its reliance on coal-fired power stations for energy generation. Over several years green economy debates have emerged and consolidated in significance in South Africa; currently they permeate strategic planning concerning national and local economic development (Borel-Saladin \& Turok, 2013b; Death, 2014; Rogerson, 2014). Of particular policy significance is the acknowledgement given to stimulating green economic development in South Africa's New Growth Path and subsequent National Development Plan as well as the Green Economy Accord, a response to climate change concerns, which established a national 'green partnership' (Rogerson, 2014).

During 2010-2011 the Department of Economic Department of Gauteng province, South Africa's economic heartland, was mandated to implement strategies for green economic development in the province. The concept of establishing a CIC in South Africa materialised in 2011 as a partnership between the Gauteng Department of Economic Development, the Innovation Hub (the innovation agency of Gauteng Province), and the World Bank InfoDev unit. During 2012 the Climate Innovation Centre of South Africa (CICSA) launched in Pretoria as a strategic green economy initiative to assist with implementation of the province's Green Growth Strategy. Its location is a science and technology park in Pretoria, South Africa's administrative capital. The CICSA, the second operational CIC in the World Bank's global network, functions as a technology and business incubator committed to support South African start-ups and existing small businesses operating in the green economy. More specifically, CICSA seeks to accelerate the growth of innovative clean tech enterprises in Gauteng towards low carbon growth paths (CICSA, 2016). Its operations are funded primarily by the Gauteng Provincial Government rather than by international donors such as the World Bank. The first two years of CIC operations were financed from the Department of Environmental Affairs Green Fund but after that ceased operations in March 2017 core financial responsibility has passed to the Gauteng Department of Economic Development.

By 2017 the CICSA had 62 clean tech enterprises in their portfolio. At the outset of operations CICSA accepted entrepreneurs from a number of different sectors, including agroprocessing, green building, energy, transport, water or waste. Since 2016/2017, however, the South African CIC has narrowed its focus to the three sectors of energy, waste and water. In 201750 percent of the CICSA portfolio comprised start-ups in the energy sector. This particular focus is the result in part of the major energy crisis that South Africa has endured since 2008 which directed attention at energy saving or renewable energy projects in order to reduce the country's dependence on coal power stations. The interviews disclosed the range of enterprises at the incubator and the application of green technologies to address climate change. Examples of clean-tech start-up enterprises in the energy sector include the innovation of retrofittable plugs that measure and record the energy use of individual household items; the manufacture of containerized modular power generation equipment fitted with solar PV equipment; the production of hydraulic hybrid transmission systems for the automotive sector that provide a secondary source of energy for vehicles; the optimization of engines with a technology that improves the synergy between the turbo charger and car engine; the development of polycarbonate tubes for the production of energy-saving LED tube lights; and, a manual washing machine that does not use electricity but is a combination of a bicycle and a stationary washing machine in which peddling the bicycle powers the laundry process as well as generating electricity for other small appliances. 
The interviews revealed that green enterprises in the energy sector seek to be both environmentally-friendly as well as spread consciousness and a message about the benefits of clean technologies to the broader community. The entrepreneur specializing in engine optimization stated "climate change is therefore fundamental from a business perspective as money is saved from fuel savings but it is also fundamental from an environmental perspective". Beyond the energy sector are other innovative start-ups engaged in the sectors of water and waste. One entrepreneur uses biogas made from animal waste in order to produce methane gas for cooking and heating in rural areas and is extending this concept to the municipal scale utilising sewage in order to generate electricity. Another clean-tech startup applies a biotechnological process of vermicomposting to turn waste destined for dumping sites into organic fertiliser and an organic pest repellent. Road construction in an environmentally-friendly manner is another focus for an innovative entrepreneur using zero slump rather than conventional concrete or steel. Finally, in terms of the water sector, one illustration is an

enterprise innovating a new technology for telemetry and water mapping which allows for leakages as well as water usage to be accurately monitored.

The recruitment process of start-ups to the CIC was investigated with both managers of the $\mathrm{CIC}$ and with the entrepreneurs. It was argued by the CIDSA green economy manager that at the time of its launch the awareness of the CIC was low and that "it was not visible enough" apart from those enterprises already operational in the green economy space. Accordingly, in order to heighten awareness of its operations and opportunities, a general manager for marketing was appointed. To recruit innovative entrepreneurs the CIC issues an open call on social media platforms such as Linkedin, Twitter and Facebook, as well as advertising through newspapers, radio, and electronic fliers. For responses to its invitation to apply to the CIC, an online application process is used but also 'walk-in' applications are allowed. Further, the CIC itself seeks to identify possible candidates which it approaches as potential candidates for incubation.

From the 20 interviews a variety of channels emerge as to how entrepreneurs became aware of the CIC and its operations. Half of the sampled interviewees were referrals or through word of mouth. Respondents stated as follows: "Through a friend who referred us. He is in government and when the CIC call came up he knew our technology so he referred us to the CIC" (automotive sector entrepreneur) and "We approached the Gauteng Infrastructure Department and they directed us to the Innovation Hub" (entrepreneur generating energy from animal waste). Three start-ups were introduced to the CIC through participating in a green competition with the winners receiving seed funding and incubation at the CIC. The entrepreneurs elaborated that: "I won a competition for a green project and part of the prize was being incubated by the CIC" (entrepreneur developing electric vehicles) and "We received electronic marketing material for the opportunity to take part in the Innovation Hub Green Challenge in 2014 and as runner up we were provided with the opportunity for incubation with the CIC" (entrepreneur in hybrid solar technology). For the remaining 7 entrepreneurs, one responded to a newspaper advertisement, two discovered the CIC through random emails that they received, two through Google internet search, and two via social media platforms. The start-up linked to engine optimization responded: "I received an email regarding the CIC and then I contacted them". 
Table 1: Criteria for consideration in admittance to CIC Incubator Programme

\begin{tabular}{|c|c|}
\hline Criteria & Detail \\
\hline Location & Projects must be implemented in Gauteng province \\
\hline Concept & $\begin{array}{l}\text { The project must be advanced beyond the idea phase } \\
\text { to a working prototype ie proof of concept or small- } \\
\text { scale demonstration }\end{array}$ \\
\hline Competitiveness & $\begin{array}{l}\text { In comparison with current technologies the project } \\
\text { should be competitive and enhance the transition } \\
\text { towards a green economy. }\end{array}$ \\
\hline Role in climate change & $\begin{array}{l}\text { Project should increase awareness of climate change } \\
\text { in both developed and especially underdeveloped } \\
\text { areas. }\end{array}$ \\
\hline Innovative technology & $\begin{array}{l}\text { Project must be a clean technology innovation that is } \\
\text { new to South Africa }\end{array}$ \\
\hline Job creation & $\begin{array}{l}\text { Once commercialized the project should create } \\
\text { various sustainable quality job opportunities }\end{array}$ \\
\hline Skills development & $\begin{array}{l}\text { Project implementation should include capacity and } \\
\text { skills development }\end{array}$ \\
\hline Economic growth & Contribution to economic growth \\
\hline Sustainability & Indication of project sustainability and viability \\
\hline Project team profile & $\begin{array}{l}\text { Team competence, extent of projects involvement in } \\
\text { the community and contribution to Black Economic } \\
\text { Empowerment. }\end{array}$ \\
\hline
\end{tabular}

Source: The Innovation Hub, 2016 (adapted by Maruschka Gonsalves).

The CIC screens the various applications that it receives against a set of ten criteria for admission to the incubator as shown on Table 1. Overall for enterprises to be accepted into the incubation programme they must be aligned with the three primary goals of CIC, namely to advance the prospects of achieving sustainable development, facilitate a transition to a green economy through innovative green technologies and make a positive contribution to climate mitigation and adaptation. Shortlisted candidates from the screening process are invited to pitch their prototype in front of a board comprised of both internal and external specialists who use a six component scoreboard to evaluate the green prototypes. Among critical elements are the evaluation of the business case for the product, whether the technology addresses an existing market need and can be protected as intellectual property, the business as well as technical skills of the entrepreneur, the extent to which the entrepreneur is viewed as determined, ambitious, motivated and potentially coachable, strategic fit in terms of the project in relation to the CIC, and finally whether the services that can be offered are sufficient for the developmental needs of particular enterprises.

At inception of operations the CICSA offered only a pre-incubation programme - known as the factory programme - to enterprises which extended between 9 and 12 months. This programme began in 2013. Following completion of the factory programme enterprises graduated into the core programme - termed the Maxum revenue incubation programme that lasts up to three years. During 2016/2017 this structure was changed as CIC introduced a full incubation programme that 'walks the road' with enterprises until they graduate which is deemed as occurring only once the enterprise is commercialized and makes its first sale. It was made clear by CIC managers that incubation does not end with commercialisation and that beyond the initial commercialization: "We assist you with advanced mentoring. We try to assist you with access to market and we try to assist you with better funding if you need to expand" (Senior Project Specialist CICSA).

According to a Senior Manager CICSA is now required to accept into its programme a total of 20 new businesses each year with a target of five enterprises to graduate from incubation 
per year. Nevertheless, monitoring of the performance of enterprises through the CIC programmes has been one of organization's major challenges. The initial structure of CIC operations with only the pre-incubation programme made it difficult for accurate records to be maintained of how many businesses were successfully graduated. This changed with the move to the full programme to commercialization which permits closer motoring and improved record keeping. From the interviews conducted with the 20 enterprises it was evident they were in various phases of the incubation process, albeit some respondents were unclear as to their actual incubation status. In terms of the 20 interviewees five were commercialized, three on the verge of commercialization, five were incubating, three graduated, one had exited the programme and three were completely unsure of their status. Of concern is the status of certain enterprises which are supposed to be still part of the incubation process but uncertain of their situation because of lack of communication about their status.

The services offered by the CICSA to potential incubator candidates are typical of those of the global network of CICs as a whole. On offer to climate technology start-ups and enterprises is so-termed "flexible stage appropriate risk capital" with resources concentrated in the early growth phase through grant, seed and scale-up financing (Climate Innovation Centre, South Africa, 2018: 1). The core aim for CICSA is to speed up the technology commercialization process. This said, the CIC stakeholders made clear that the primary function of the organisation was not funding per se: "incubators are not funders" (CIC Senior Manager). Enterprises are assigned to service organisations partners who can assist with securing access to funding. It was made clear by one CIC interviewee that "those that come just for money are doomed to failure" (CIC Project Coordinator). In addition to access to finance, entrepreneurs are offered access to modern equipment and facilities, including technical laboratories to assist with prototyping, testing and proof of concept for these innovators. Packages of business training, technical advice from experts in climate friendly, clean technology sectors, and mentorship are given in order to "equip local citizens with the necessary skills to generate and sustain an innovation pipeline" (Climate Innovation Centre, South Africa, 2018: 2). For the CIC Senior manager it was maintained "the key service offering of the CIC is mentorship". Incubator enterprises are assigned to applicable business and technical mentors for advice and each receives "every month three hours of business mentoring and three hours of technical mentoring by means of training courses and workshops" (CIC General Manager of the Green Economy Department). The final service offering from CICSA relates to networking which provides improved access to markets for enterprises through introductions made to different role players in the particular sector as well as local and national (and in some cases even international) partners.

The 20 interviewed enterprises were requested to assess the most valued service offered by CICSA. Most responded that more than one service was highly valued. The results showed that 18 enterprises identified mentoring as the most important service. One entrepreneur in renewable energy elaborated that "the mentorship is valuable as there is someone (the mentor) who can challenge my thoughts and direction around the concepts and identify gaps in the business model". Eight of the 20 enterprises viewed funding as the most critical service with two enterprises using the fund grant that they had obtained for filing a patent application. The comment was offered that patenting as intellectual property was crucial as it "builds a fence that protects the idea" (Entrepreneur in automotive sector). Networking opportunities through CICSA were acknowledged as significant by six respondents. A typical response from an entrepreneur in waste recycling was "the contacts that they made available to me are extremely valuable". Only three entrepreneurs identified infrastructural services, in 
terms of office space, telephone lines, internet and meeting rooms, as the most valued service offering. It was reflected, however, by one respondent that the shared office spaces "allows one to meet other entrepreneurs and to share experiences and advice" (Entrepreneur in waste recycling).

In terms of the impact of the CICSA incubator support on the survival and growth of enterprises only preliminary assessment can be offered as the organisation has been in existence for only a period of five years. It is evident that a number of enterprises have exited the programme after the prototype of the enterprise failed and the CIC does not afford flexibility to work with failures. Moreover, as the CIC initially offered only the preincubation programme it did not follow up on the status of enterprises after their graduation into the Maxum programme. The four CIC interviewees all maintain that the organisation has made a positive impact to enterprise survival with the Project Coordinator asserting that if no value was added for them "enterprises would have left the programme from as early as the first week". From the perspectives offered by the enterprises 15 of the 20 interviewees considered that they would have succeeded without the CIC intervention with one respondent adding "Yes, I would have succeeded without the help from the CIC but it would have taken me longer without the help from CIC" (Entrepreneur in energy sector). This sentiment was also expressed by a manufacturer of electric vehicles: "Of course we would have succeeded but it definitely would have taken longer and there would have been a lot of hurdles which we could not have been able to foresee and plan for. The CIC played a pivotal role in making sure the company is successful". Overall. three-quarters of the interviewed enterprises considered that whilst the CIC programmes cannot be attributed as the sole factors behind their success, the assistance programmes provided by CICSA are valuable and undoubtedly reduced the time period for the transition towards commercialization.

Finally, some challenges emerged from the qualitative interviews with both CIC managers and enterprises. The issue of monitoring the progress of enterprises has earlier been flagged. Another specific monitoring issue is that currently "the CIC does not have an instrument to monitor their impact on emission reductions" (CIC Senior Project Specialist). The absence of a direct monitoring for emissions reduction was conceded as a shortcoming by the Senior Manager:

Our (performance) matrix at the moment is jobs, number of companies and revenue or funding leverage. Those are the three main things along with other socio-economic factors that you have to track. We do not track CO2 reductions. We report to the World Bank quarterly and based on the type of companies we support, their products and the number of products they have sold the World Bank are able to estimate CO2 potential. However, most CIC companies are not trading yet; they are still in their pre-revenue stage. Maybe, in the long run we should be able to estimate how many tons of CO2 we have saved.

Other critical challenges for future CIC operations emerged in the research. Capacity issues in terms of sufficient human resources and staffing were raised. Another human resource issue was the high staff turnover at $\mathrm{CIC}$ which, at one point, was so severe that "managers would only stay for a year" (CIC General Manager). The quality of certain of the mentors was an additional concern. One respondent vented that "the assistance from the business and technical mentor was of zero value to us. The mentoring was a waste of time and money. There was no interaction, feedback or follow-up from the mentor's side" (Automotive entrepreneur) Finally, enterprises complained often of the difficulty of accessing funding to progress their development. It was stated that the CIC should be more pro-active in finding sources for enterprise funding particularly as start-up financing is crucial for enterprise 
survival. Moreover, even for those enterprises whose applications for funding are approved complaints were raised about the slow release of funds which only "are paid out in dribs and drabs" (Entrepreneur in energy)

\section{Conclusion}

The role of business incubators in reducing the high mortality rates which are experienced by start-up enterprises is a critical issue for the African development agenda (Rogerson, 2018a). One observed trend is towards the establishment of dedicated business incubator targeted at specific sectors of enterprises such as those in agribusiness, culture or tourism. It is set against the backdrop of global climate change and the reorientation towards a low-carbon, green growth pathways that Climate Innovation Centres represent a distinctive form of business incubator targeted to accelerate the development, deployment and transfer of locally relevant climate technologies in the global South.

This research is the first of its kind to analyze the establishment and operations of South Africa's Climate Innovation Centre. Arguably, the CICSA in its first five years of operations has been 'learning through experience' and introduced a number of changes since its launch in 2012. The study reveals the particular character of the CIC which adjusted its focus to South Africa's core climate change related 'green' issues around energy, water and waste. Important changes were made also in terms of the extension of the business incubation programme. Although it might be argued that the time period of five years in operation is too short for a full evaluation of CIC operations the evidence from this research with South African clean-tech enterprises is largely positive. In particular, the findings suggest that the assistance provided by the CIC is valuable, if not a pivotal influence, for assisting enterprises engaged with the green technologies.

Maruschka Gonsalves, Department of Geography, Environmental Management \& Energy Studies, University of Johannesburg, Johannesburg, South Africa (maruschka.gonsalves@angloamerican.com)

Jayne M. Rogerson, School of Tourism \& Hospitality, College of Business and Economics, University of Johannesburg, Johannesburg, South Africa (jayner@uj.ac.za)

\section{References}

Akcomak, I. S. (2009) Incubators as tools for entrepreneurship promotion in developing countries. Helsinki, UNU-WIDER Working Papers 2009/52.

Albort-Morant, G. \& Ribiero-Soriano, D. (2016) A bibliometric analysis of international impact of business incubators. Journal of Business Research, 69(5), pp. 1775-1779. DOI: 10.1016/j.jbusres.2015.10.054

Al-Mubaraki, H. \& Busler, M. (2014) Incubator successes: Lessons learned from successful incubators towards the twenty-first century. World Journal of Science, Technology and Sustainable Development, 11(1), pp. 44-52. DOI: 10.1108/WJSTSD-08-2013-0030

Al-Mubaraki, H., Busler, M., Al-Ajmei, R. \& Aruna, M. (2013) Incubators best practices in developed and developing countries: Qualitative approaches. Asian Journal of Empirical Research, 3(7), pp. 895-910.

Borel-Saladin, J. \& Turok, I. N. (2013a) The green economy: Incremental change or transformation?. Environmental Policy and Governance, 23(4), pp. 209-220. DOI: 10.1002/eet.1614

Borel-Saladin, J. \& Turok, I. N. (2013b) The impact of the green economy on jobs in South Africa. South African Journal of Science, 109(9-10), pp. 1-4. DOI: 10.1590/sajs.2013/a0033 
Bruneel, J., Ratinho, T., Clarysse, B. \& Groen, A. (2012) The evolution of business incubators: Comparing demand and supply of business incubation services across different incubator generations. Technovation, 32, pp. 110-121. DOI: 10.1016/j.technovation.2011.11.003

Climate Innovation Centre, South Africa (2016) Accelerating the growth of innovative clean tech enterprises towards low-carbon, green growth paths. Available at: www.cicsouthafrica.co.za/home (accessed 18 Nov. 2017).

Climate Innovation Centre, South Africa (2018) Services. Available at: www.cicsouthafrica.co.za/home (accessed 26 July 2018).

Death, C. (2014) The green economy in South Africa: Global discourses and local politics. Politikon, 47(1), pp. 1-22. DOI: $10.1080 / 02589346.2014 .885668$

Georgeson, L., Maslin, M. \& Poessinouw, M. (2017) The global green economy: A review of concepts, definitions, measurement methodologies and their interactions. Geo: Geography and the Environment 4(1). DOI: $10.1002 /$ geo 2.36

Gonsalves, M. (2018) The establishment, development and organization of the Gauteng Climate Innovation Centre. Master's dissertation, University of Johannesburg, Johannesburg.

Grimaldi, R. \& Grandi, A. (2005) Business incubators and new venture creation: An assessment of incubating models. Technovation, 25(2), pp. 111-121. DOI: 10.1016/S0166-4972(03)00076-2

Hasper, M. (2009) Green technology in developing countries: Creating accessibility through a global exchange forum. Duke Law \& Technology Review No. 1, pp. 1-13.

InfoDev (2010a) Global practice in incubation: Policy development and implementation. Washington DC, The World Bank.

InfoDev (2010b) Global practice in incubation: Policy development and implementation: Brazil Incubation Country case study. Washington DC, InfoDev.

InfoDev (2010c) Kenya Climate Innovation Centre: $C I C-A$ business plan for the financing and implementation of a CIC in Kenya. Report for the Climate Technology Program. Washington DC, The World Bank.

InfoDev (2012) Gauteng Climate Innovation Centre. Available at: https://www.infodev.org/infodevfiles/resource/InfodevDocuments_1165.pdf (accessed 10 Aug. 2016).

InfoDev (2013a) Caribbean Climate Innovation Center business plan. Available at: http://www.infodev.org/infodev-files/caribbean_cic_busines_plan_draft_-_full_text.pdf (accessed 20 Apr. 2017).

InfoDev (2013b) Kenya Climate Innovation Center (KCIC). Available at: http://www.infodev.org/articles/aboutkenya-climate-innovation-center (accessed 21 Apr. 2017).

InfoDev (2014) An evaluation and impact assessment of business incubation models in Eastern Europe and Central Asia: An InfoDev study of nine business incubators in Armenia, Belarus, Kazakhstan, Poland, Romania, the Russian Federation, Serbia and Turkey. Washington DC, The World Bank.

InfoDev (2015) Fostering local solutions to climate change. Climate Technology Program. Available at www.infodev.org/climate (accessed 24 Feb. 2016).

InfoDev (2016) Innovation centers help developing countries capture climate change opportunities. Available at: www.infodev.org (accessed 12 May 2016).

InfoDev \& The Innovation Hub (2012) Gauteng Climate Innovation Center (CIC): A Business plan for the financing and implementation of a CIC in Gauteng, South Africa. Report prepared as part of the World Bank-InfoDev Climate Technology programme. Washington DC, The World Bank.

ITU, OHCHR, UNCTAD, UNEP, UNESCO, UNFCCC, UNIDO, WIPO, \& WMO (2015) UN System Task Team on the Post-2015 UN Development Agenda: Science, Technology and Innovation for Sustainable Development in the Global Partnership for Development beyond 2015. New York and Geneva, United Nations.

Kaggwa, M., Mutanga, S. S., Nhamo, G. \& Simelane, T. (2013) South Africa's green economy transition: Implications for reorienting the economy towards a low-carbon growth trajectory. Economic Diplomacy Programme, Occasional Paper No. 168. Johannesburg, South African Institute of International Affairs.

Kapinga. A. F., Montero, C. S., Mwadosya, G. I. \& Mbise, E. R. (2018) Exploring the contribution of business and technology incubators to women entrepreneurs' business development in Dar es Salaam, Tanzania. Journal of Global Entrepreneurship Research, 8(23), pp. 1-14. DOI: 10.1186/s40497-018-0111-9

Li, X. \& North, D. (2018) The role of technological business incubators in supporting business innovation in China: A case of regional adaptability. Entrepreneurship \& Regional Development, 30(1-2), pp. $29-57$. DOI: $10.1080 / 08985626.2017 .1364789$

Lose, T., Nxopo, Z., Maziriri, E. \& Madinga, W. (2016) Navigating the role of business incubators: A review on the current literature on business incubation in South Africa. Acta Universitatis Danubius Oeconomica, 12(5), pp. 130-140. 
Masutha, M. \& Rogerson, C. M. (2014a) Small enterprise development in South Africa: The role of business incubators. Bulletin of Geography: Socio-Economic Series, 26, pp. 141-155. DOI: 10.2478/bog-20140050

Masutha, M. \& Rogerson, C. M. (2014b) Small business incubators: An emerging phenomenon in South Africa's SMME economy. Urbani izziv, 25(Supplement), pp. S48-S63. DOI: 10.5379/urbani-izziv-en2014-25-supplement-004

Masutha, M. \& Rogerson, C. M. (2015) Business incubation for SMME development: South African pathways. Urban Forum, 26(2), pp. 223-241. DOI: 10.1007/s12132-014-9242-4

Mian, S., Lamine, W. \& Fayolle, A. (2016) Technology business incubation: An overview of the state of knowledge. Technovation, 50-51, pp. 1-12. DOI: 10.1016/j.technovation.2016.02.005

Ndabeni, L. (2008) The contribution of business incubators and technology stations to small enterprise development in South Africa. Development Southern Africa, 25(3), 259-268. DOI: $10.1080 / 03768350802212022$

Newell, P. \& Bulkeley, H. (2017) Landscape for change?: International climate policy and energy transitions: evidence from sub-Saharan Africa. Climate Policy, 17(5), pp. 650-663. DOI: 10.1080/14693062.2016.1173003

Nhamo, G. (2013) Green economy readiness in South Africa: A focus on the national sphere of government. International Journal of African Renaissance, 8(1), pp. 115-142. DOI: 10.1080/18186874.2013.834628

Nunan, F. (ed.) (2017) Making climate compatible development happen. Abingdon, Routledge. DOI: $10.4324 / 9781315621579$

Rogerson, C. M. (2014) Reframing place-based economic development in South Africa: the example of local economic development. Bulletin of Geography: Socio-Economic Series, 24, pp. 203-218. DOI: 10.2478/bog2014-0023

Rogerson, C. M. (2016a) Re-energising business incubation policy in South Africa: learning from international experience. In: Donaldson, R., Visser, G., Kemp, J. \& de Waal, J. (eds) Celebrate A Century of Geography: Proceedings of the $11^{\text {th }}$ Biennial Conference of the Society of South African Geographers, pp. 22-29. Stellenbosch, Society of South African Geographers.

Rogerson, C. M. (2016b) Climate change, tourism and local economic development in South Africa. Local Economy, 31(1-2), pp. 322-331. DOI: 10.1177/0269094215624354

Rogerson, C. M. (2018a) Supporting the SMME economy of sub-Saharan Africa: A role for business incubation. In: Binns, T., Lynch, K. \& Nel, E. (eds.) The Routledge Handbook of African Development, pp. 532-544. Abingdon, Routledge.

Rogerson, C. M. (2018b) Innovation-driven local economic development: In search of best practice implementation for South Africa. Euroeconomica, 37, pp. 15-28.

Sagar, A. (2010) Climate Innovation Centres: Technology cooperation to meet climate challenges. Delhi, Indian Institute of Technology.

Sagar, A. \& Bloomberg New Energy Finance (2010) Climate Innovation Centres: A new way to foster climate technologies in the developing world? Washington DC, Infodev.

Sagar, A. D., Bremner, C. \& Grubb, M. (2009) Climate Innovation Centres: A partnership approach to meeting energy and climate challenges. Natural Resources Forum, 33(4), pp. 274-284. DOI: 10.1111/j.14778947.2009.001252.x

Scholes, R. J., Scholes, M. \& Lucas, M. (2015) Climate Change: Briefings from Southern Africa. Johannesburg, Wits University Press. DOI: 10.18772/22015119186

Tengeh, R.K. \& Choto, P. (2015) The relevance and challenges of business incubators that support survivalist enterprises. Investment Management and Financial Innovations, 12(2), pp. 150-161.

Theodorakopoulos, N., Kakabadse, N. K. \& McGowan, C. (2014) What matters in business incubation? A literature review and a suggestion for situated theorising. Journal of Small Business Enterprise Development, 21(4), pp. 606-622. DOI: 10.1108/JSBED-09-2014-0152

Ziervogel, C., New, M., Archer van Garderen, E., Midgley, G., Taylor, A., Hamann, R., Stuart-Hill, S., Myers, J. \& Warburton, M. (2014) Climate change impacts and adaptation in South Africa. WIREs Climate Change 5 (September/October), pp. 605-620. DOI: 10.1002/wcc.295 